\title{
Paekche King Künch'ogo's Twisted Journey to the South: A Textual and Archaeological Perspective
}

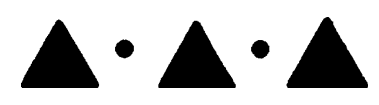

Dennis LeE

ABSTRACT

Since the 1950s, most Korean scholars have believed that Paekche King Kŭnch'ogo (r. A.D. 346-375) expanded his territory southward from his base in the Han River basin (present day Seoul) to encompass the entire southwestern Korean peninsula in A.D. 369. Although the nature of his southern conquest has been debated by scholars, the conquest itself has rarely been questioned. Upon closer inspection, however, we find that the sole historical source, the Nihon shoki (compiled A.D. 720), does not describe a Paekche conquest but a punitive military expedition from the Japanese archipelago. This account was later used to justify Imperial Japan's annexation of Korea in 1910. This article explores the twisted historiographical journey of this ambiguous passage from an early Japanese hagiography and its transformation from a tool of Japanese imperialism into an unquestioned Korean narrative of Paekche territorial expansion. A critical examination of the original text and the archaeological context of this supposed Paekche invasion into the southwestern Korean peninsula suggests that such a dramatic southern Paekche expansion was unlikely to have taken place as early as the late fourth century A.D. KeYwords: Paekche, Kŭnch’ogo, Jingū, Mimana Nihonfu, early Korea-Japan relations.

\section{INTRODUCTION}

HiSTORICAL TEXTS ARE POWERFUL: Timeworn words capturing ancient truths command instant reverence for the uncritical reader. In East Asia, the incredible influence of historical accounts in shaping our understanding of the past can best be described as hegemonic, at times drowning out or distorting the findings of other disciplines, particularly archaeology. Ideally, textual and archaeological approaches complement each other to offer a more complete picture of the past. Unfortunately, discordances can arise, so a careful reexamination of the data is required. Mark Byington (this issue) works with this in his identification of royal Koguryŏ tombs based on historical texts and archaeological materials. He allows the archaeology to speak for itself without letting historical texts dominate his interpretation. In his exploration of ritual boundaries in the Iron Age in southeastern Korea, Jack Davey (this issue) also struggles with the problem of dividing the Korean peninsula into arbitrary polities culled from historical texts.

Here I explore another case of textual hegemony in the A.D. 369 southern expansion of the Paekche 百濟 kingdom (trad. 18 B.C.-A.D. 660) under King Kŭnch'ogo 近肖古王 
(r. A.D. 346-375), from its core in the Han River basin (present-day Seoul) to the entire southwestern Korean peninsula. Although the exact details of this southern advance have been debated by scholars, the conquest itself has rarely been questioned since the 1950s. Mainstream interpretations of archaeological data suggest that Paekche did indeed expand completely into the southwestern Korean peninsula by the early sixth century, as evidenced by the change in burial styles and erection of Paekche-style fortresses in the region. However, these changes do not seem to begin until the late fifth century, long after the supposed conquest of 369. In an attempt to resolve this chronological gap, this article traces the origins of King Kŭnch'ogo's southern conquest theory, critically examines the original historical text, and looks at the archaeological context to evaluate the validity of this historical narrative. If such a Paekche expansion did not occur in A.D. 369, the southwestern Korean peninsula from the late fourth century on could no longer be framed as simply part of Paekche, but would instead have to be treated as an independent region, with its own archaeology and history.

\section{TEXTUAL BACKGROUND}

Paekche is of great interest to early Korea and Japan scholars for its close ties with the Japanese archipelago, particularly the polity of Yamato (ca. A.D. 200-710), as well as its role in transmitting culture and technology there. It is also one of the traditional kingdoms of the "Korean" Three Kingdoms period (trad. 57 B.C.-A.D. 668), the other two being Silla 新羅 (trad. 57 B.C.-A.D. 935) and Koguryŏ 高句麗 (trad. 37 B.C.-A.D. 668). These polities dominated the Korean peninsula between the fourth and seventh centuries A.D. until Silla conquered its neighbors by A.D. 668 (Fig. 1).

Our understanding of Paekche's development comes primarily from textual sources, which include Chinese dynastic histories such as the Sanguozhi 三國志 (Records of the Three Kingdoms) compiled in the late third century A.D. (hereafter cited SGZ [2018]) and the Jinshu 育書 (Book of Jin) compiled A.D. 648 (hereafter cited JS [2018]), the early Japanese history Nihon shoki 日本書紀 (Chronicles of Japan) compiled A.D. 720 (hereafter cited NS [1994]), and early Korean histories such as the Samguk sagi 三國史記 (Historical Records of the Three Kingdoms) compiled A.D. 1145 (hereafter cited SGSG [2004]). ${ }^{1}$ Unfortunately, these sources provide only limited and fragmentary information regarding Paekche, which makes it difficult to rely on them without a critical reading. For instance, Chinese dynastic historical texts barely mention Paekche. In the rare instances when they do, it is usually within the context of Paekche diplomatic missions to their courts. The one possible exception is the late third century Sanguozhi, which merely describes contemporary Paekche as one of more than fifty Mahan 馬韓 polities distributed throughout the western half of the Korean peninsula south of present-day P'yŏngyang. The "Account of the Mahan" in the Sanguozhi did not contain any details about Paekche's development and was written from the perspective of the "civilized" Chinese central government commenting on the "barbarians" in the frontier. The sources of this and other parts of the Sanguozhi are not known, but such a brief account of a "barbarian" society seems to be an afterthought reflecting the cultural and racial prejudices of the anonymous compilers.

The Japanese historical text Nihon shoki 日本書記 also contains information about Paekche, but it too only provides fragmented accounts usually framed within a hagiographic narrative of the Japanese imperial family. This makes sense since it was 


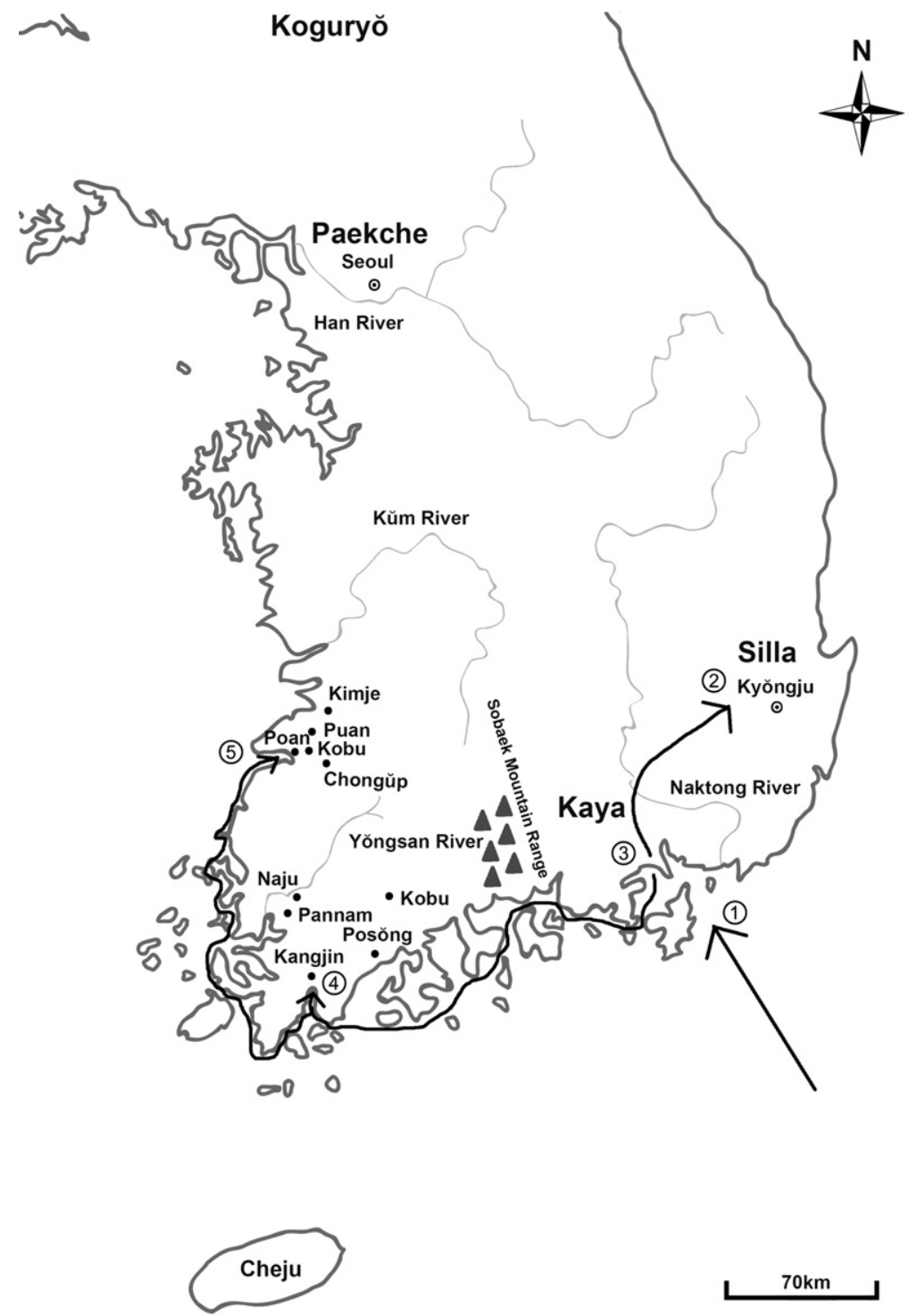

Fig. 1. Overview of the Korean Peninsula with approximate locations of major historical polities.

probably written to legitimize the Japanese imperial family's rule in the eighth century A.D. Japanese accounts dated prior to the Asuka period (A.D. 538-710) become more unreliable the further back they go, while the stories grow more fantastic and seem intent on pushing anachronistic claims of a unified Japanese empire since ancient times. Most of the accounts of earlier times have been dismissed as mythical or as relating later events as if they had happened in an earlier period (Best 2006). Again, this text must be examined critically if it is to be relied upon.

Although the earliest extant Korean history, the Samguk sagi contains the richest historical information about Paekche, it is still fragmentary and problematic. Paekche 
had been gone for more than five centuries by the time Kim Pusik compiled the Samguk sagi; even he acknowledged that information about Paekche was incomplete because of the scarcity of early written records (SGSG 2004). Chronological issues and contradictory records also make using the Samguk sagi problematic, but it is the best historical source of data on Paekche we have (for a critical discussion, see Best 2006).

Returning to the topic of King Kŭnch'ogo's southern expansion of 369, one would expect that a doubling or even tripling of Paekche territory would have been prominently recorded in official state history and thus be found in the Samguk sagi, yet the Samguk sagi does not mention any southern military campaigns that year. Instead, it focuses on the military threat of Paekche's northern rival Koguryŏ, which was expanding south from its base in Manchuria. Lack of a historical record does not necessarily mean that the southern conquest did not happen, however. The fragmentary nature of the Samguk sagi suggests that many Paekche records have been lost over time.

If not from Korean history, where did this idea of King Kŭnch'ogo's glorious southern advance come from? All proponents of this theory point to the Nihon shoki, more specifically in a passage concerning the forty-ninth year of Empress Jingū's reign 神功皇后 [hereafter Jingū 49]. The original dating for this record was A.D. 249, but it has been clocked two sexagenary cycles or 120 years later, putting it at A.D. 369 (Szczesniak 1952). Oddly, this passage says nothing about a Paekche conquest of the southwest peninsula and instead describes a punitive expedition against Silla originating from Yamato in the Japanese archipelago. How did a record of a Yamato raid against Silla turn into a story about a massive Paekche conquest of the entire southwestern Korean peninsula? The answer lies in some creative early twentieth century interpretations of this passage.

\section{COLONIAL ORIGINS AND SOUTH KOREAN ADAPTATION}

In the late nineteenth century, Japan's modernization project and conversion to an imperial nation-state required the writing of a national history, particularly one that supported irredentist claims on neighboring states such as Korea. The debates during the previous Edo period (1603-1868) on the origins of Japan from the continent and kinship ties with the Korean peninsula gave way in the late nineteenth and early twentieth century to discussions on ancient Japan's territorial expansion into the Korean peninsula. For imperialist Japanese scholars, the Nihon shoki, one of the earliest known Japanese historical texts, served as historical evidence of ancient Japanese hegemony over the Korean peninsula through its accounts of military attacks on the Korean peninsula in ancient times. The section that particularly excited these imperialist scholars was the account of Empress Jing $\bar{u}$, who supposedly conquered Silla in A.D. 320 and awed Paekche and Koguryo into pledging their allegiance to Yamato soon afterward. The Jingū 49 record, the passage most relevant to this discussion, describes a military operation to "punish" Silla and "pacify" the Kaya region over a diplomatic incident between Silla and Paekche (NS 1994:457).

In the late nineteenth century, imperialist Japanese scholars such as Naka Michiyo and Kan Masatomo argued that this Yamato punitive military expedition led to the establishment of the Mimana Nihonfu 任那日本府 (lit. “Mimana Japanese Governmental Office"; Kor. Imna Ilbonbu) to politically and militarily control the Kaya region and manage affairs in the southern Korean peninsula (Tanaka 2008). ${ }^{2}$ The Mimana Nihonfu operated until Silla annexed it sometime in the sixth century 
A.D. From the perspective of Imperial Japan, this provided a historical precedent for invading the Korean peninsula to supposedly restore the status quo ante. This Mimana Nihonfu theory, however, had very little to say about the southwestern section of the Korean peninsula, roughly corresponding to the present-day Chŏlla provinces. Kaya was assumed to be a collection of polities in the Naktong River basin. If the Mimana Nihonfu had control over the southwestern Korean peninsula, it was never explicitly mentioned until historian Tsuda Sökichi (1913) speculated that some of the places named in the Jingu 49 record could have been in the southwestern Korean peninsula. It was Suematsu Yasukazu's (1961) work in the 1930s, however, that solidified the idea that ancient Japan (i.e., Yamato) had conquered all of the southwestern region of the Korean peninsula. He tried to support this idea by discerning phonetic correspondences between place names found in the Jingū 49 record with the names of Mahan polities (supposedly located in the southwest) listed in the Sanguozhi. Suematsu, in effect, argued that ancient Japan ruled the entire southern half of the Korean peninsula (Silla in the southeast, Kaya in the south, and the southwestern region) with Paekche and Koguryŏ (extending into Manchuria) acting as vassal states. This idea of an ancient Japanese conquest of the southwestern Korean peninsula became firmly entrenched among imperialist Japanese historians during the period of Imperial Japanese colonization of Korea (1910-1945). Vestiges of this theory continue to circulate within Japanese academia today, even after Imperial Japan's defeat in 1945.

Korea's liberation in 1945, however, allowed Korean historians, especially those who had trained in Japan, to freely rethink much of the colonial scholarship on early Korean-Japanese relations. One of these scholars, Yi Pyŏngdo (1959), argued that many of the early Japanese entries regarding the Korean peninsula were actually Paekche records that were repurposed as Yamato ones during the compilation of the Nihon shoki. Yi Pyŏngdo reasoned that Yamato lacked the technological sophistication and military might to invade the Korean peninsula at such an early date, so he "corrected" the main protagonist of the Jingū 49 record from Empress Jingū of Yamato to her contemporary, King Kŭnch'ogo of Paekche. ${ }^{3}$ As the first historically verifiable Paekche king, Kŭnch'ogo is known for his successful campaigns against the northern enemy Koguryŏ, including one in recorded for A.D. 371 (SGSG 24 [Kŭnch'ogo 26]). ${ }^{4}$ He also proactively pursued diplomacy with Yamato starting A.D. 369 (JS 9 [Xianan 2.1]); SGSG 24 [Künch'ogo 27.1]) and the Eastern Jin 東晉 (A.D. 317-420) in A.D. 372 (JS 9 [Xianan 2.1]; SGSG 24 [Künch'ogo 27.1]). Most importantly, he appeared in the original Jingū narrative. Therefore, replacing Empress Jingū with King Kŭnch'ogo would not have required much manipulation of the text.

Ultimately, the idea of an ancient Japanese conquest of Korea was unthinkable and unacceptable to Korean nationalist historians. Yi Pyŏngdo's argument rapidly gained currency within Korean academia, conveniently explaining away any possible Japanese claim to the Korean peninsula. Once Yi's theory of Paekche's southern conquest became accepted into Korean nationalist history as undisputed fact, the details of the conquest could be debated, but the core narrative of a southern territorial expansion would remain essentially the same. Yet neither Yi nor any of his followers challenged Suematsu's notion that one polity or another had conquered or expanded into the southwest Korean peninsula. We may now ask: Does the original text describe an acquisition of territory, regardless of whether the invading force was Yamato or Paekche? 


\section{CRITICAL REVIEW OF JINGŪ 49}

In order to understand the reason behind the military expedition mentioned in Jing $\bar{u}$ 49, I briefly describe the events that led up to it. The Nihon shoki records a Yamato envoy first making contact with Paekche in A.D. 366 via the Kaya polity of T'aksun 卓淳 (J. Tokuju) in A.D. 366 (NS 9 [Jingū 46.3]). Apparently, King Kŭnch'ogo presented gifts to the Yamato envoys and expressed interest in obtaining directions to Yamato. King Kŭnch'ogo sent Kuje 久氏 (J. Kute), Mijuryu 彌州流 (J. Mitsuru), and Makko 莫古 (J. Mako) to pay “tribute” to the Yamato court the following year (NS 9 [Jingū 47.4]). ${ }^{5}$ The Silla envoy to Yamato, however, captured the Paekche envoy, switched their own inferior Silla tribute with Paekche's superior goods, and threatened to kill them. This prompted the Yamato court to send a military expedition to punish Silla for this diplomatic offense. My translation of the original Jingu 49 text is as follows (NS 9 [Jingū 49.3]):

Year 49 [A.D. 369], Spring, Third Month. Areda-wake 荒田別 and Kaga-wake 鹿我別 were appointed as generals. ${ }^{6}$ Together with Kuje, they led troops and crossed the sea to the land of T'aksun. They were about to invade Silla when someone said, "If you do not have enough troops, you will not be able to defeat Silla." Therefore, Sahaku 沙白 and Kafuro 蓋盧 were sent back to request reinforcements. Mongna Kŭnja 木羅斤資 [J. Mokura Konshi] and Sasa Nogwe 沙沙奴跪 [J. Sasa Naku] (these two men's kabane [court titles] are not known, but Mongna Künja was a Paekche general) were ordered to command an elite force and dispatched along with Sahaku and Kafuro. ${ }^{7}$ Assembling at T'aksun, they invaded Silla, conquering it. After pacifying the seven lands of Pijabal 比自㶱 [J. Hishiha], South Kara 南加羅 [J. Arihishi no Kara], the land of T'ak 㖨國 [J. Toku no Kuni], Alla 安羅 [J. Ara], Tara 多羅, T’aksun, and Kara 加羅, they turned westward and arrived at Kohaejin 古爱津 [J. Koke no Tsu], where they slaughtered the southern barbarians of Ch'immidarye 忱彌多禮 [J. Tomutare] and bestowed it on Paekche. The [Paekche] King [Kŭn]Ch'ogo [J. Konikishi Shōko] and Prince Kwisu 貴須 [J. Seshimu Kuisu], rendezvoused with them with their army. At that time, the four towns of Piri 比利 [J. Hiri], Pyŏkchung 辟中 [J. Hechū], P'omiji 布彌支 [J. Homuki], and Pan'go 半古 [J. Hanko] surrendered on their own accord. The Paekche king and his son then received Areda-wake and Mongna Kŭnja at Ǔiryu Village 意流村 [J. Orusuki] (now called Churyusugi 州流須祇 [J. Tsurusuki]), and they were all delighted to see each other. They were then sent off with great courtesy.

Several points stand out from the original text. First, the original mission was to punish Silla and not to expand territory. Although punitive military expeditions can include territorial acquisition, the fact that the Kaya region and Silla continued to operate independently after these events within the Nihon shoki's own narrative suggests that this was more of a raid to terrorize Silla rather than conquer it; this is also consistent with Silla's records. ${ }^{8}$ Second, this was a joint Yamato-Paekche military operation. From the onset, the Paekche figures were in joint command of this expeditionary force. Kujŏ, for example, is not described as having a military title but nevertheless was “commanding troops" (J. ikusa wo totono 勒兵) along with the Yamato generals. In addition, Mongna Kŭnja, one of the commanders of the elite force, is clearly identified as a Paekche general in the interlinear comments. Third, instead of returning to Yamato, the joint Yamato-Paekche forces headed west in the opposite direction, which would only make sense if they were going to Paekche. This is confusing because, if the original mission was only intended to punish Silla, they 


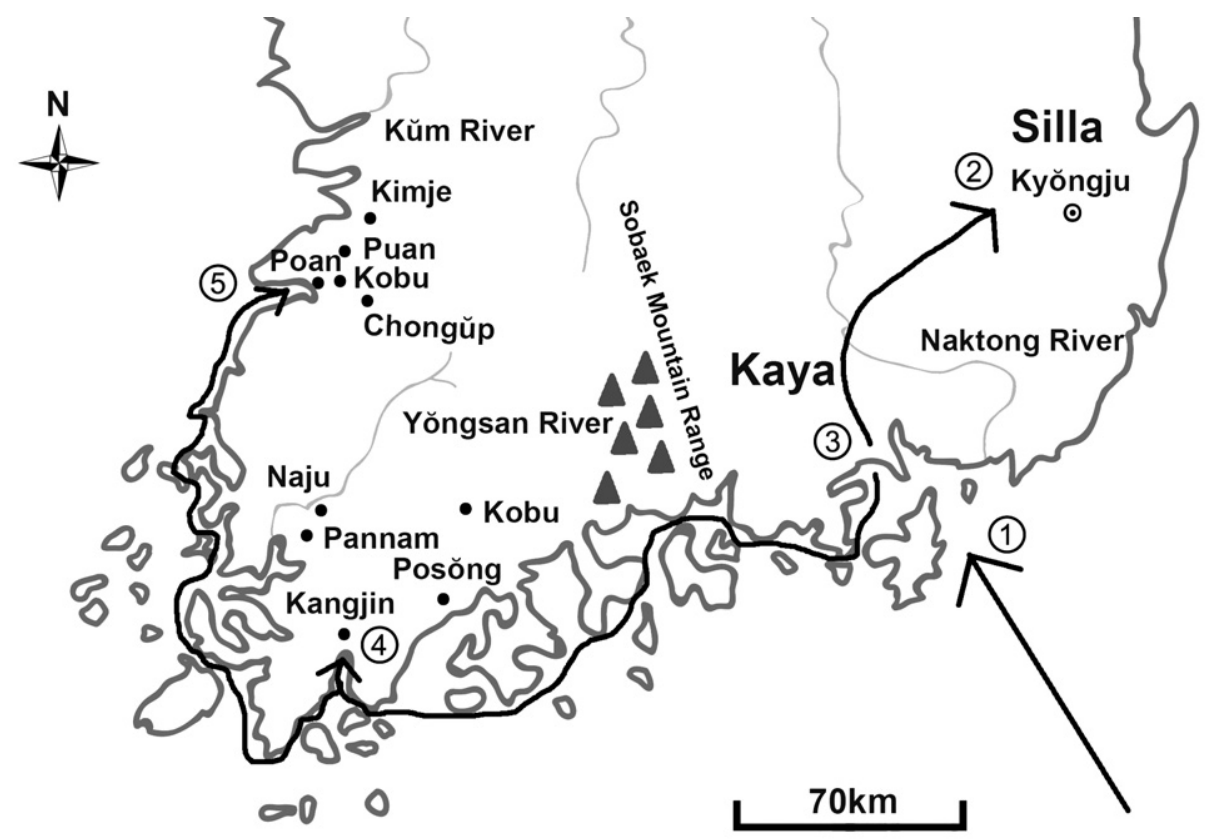

Fig. 2. Hypothetical route of the joint Yamato-Paekche military in A.D. 369 (illustration prepared by Saehyun Lee).

should have returned to Yamato afterwards. However, the narrative has three main acts. First, Yamato forces sail to the peninsula (Fig. 2-1) to punish Silla (Fig. 2-2) and "pacify" the Kaya region (Fig. 2-3); second, they move west to slaughter "southern barbarians" at Ch'immidarye (Fig. 2-4); and finally, they rendezvous with King Künch'ogo and his son, after which several towns surrender to them (Fig. 2-5). Read at face value, no grand territorial expansion occurred.

The connection to the southwestern Korean peninsula in this text is based on the interpretation of the place names for Kohaejin, Ch'immidarye, and surrendering towns. The lack of certainty regarding the locations of these places is one of the text's largest problems and the reason for its many diverging interpretations. The general approach to finding the present-day equivalents of place names in the texts is to look for phonetic correspondences in historical geographic records such as the “Monographs of Geography" 地理志 section of the Samguk sagi (SGSG 34-37:370401) and the Sinjŭng Tongguk yŏji sŭngnam 新增東國輿地勝覽 (New Augmented Survey of the Geography of Korea, compiled in 1530) (Kojŏn 1994). The problem with this approach is that place names were recorded in Chinese characters, which either tried to approximate the native pronunciation of the place name (e.g., presentday Shou'er 首尔 for Seoul) or translated its meaning into equivalent Chinese characters (e.g., Ungjin 熊津, a literal translation of komnaru or "bear port"). The pronunciation of these characters changed over time and across languages, so the original sounds are unknown. This has not stopped scholars from trying to uncover correspondences, but unfortunately this approach is ultimately pure speculation. Nevertheless, the geographical guesswork done by the earlier generation of scholars 
such as Suematsu Yasukazu (1961) and Yi Pyŏngdo $(1959,1976)$ has become generally accepted and remains unquestioned within the Korean and even Japanese academic communities. Next, I examine the merits of the most commonly accepted locations for the places named above.

\section{Kohaejin}

Yi Pyŏngdo $(1959,1976)$ argued that Kohaejin 古爱津 was present-day Kangjin in South Chŏlla Province. ${ }^{9}$ His reasoning went as follows. First, the "Kohae" in Kohaejin sounds remarkably like the name of the Mahan polity Kuhae 狗奚國 found in the Sanguozhi. Second, according to the list of old names (kojǒk 古蹟) for Kangjin County 康津縣條 in the New Augmented Survey of the Geography of Korea, Kangjin used to be called Kugyeso 舊溪所, and Kugye sounds similar to "Kuhae" 狗奚 and "Kohae" 古爱. ${ }^{10}$ Therefore, present-day Kangjin must be Kohaejin. This, unfortunately, is the extent of the evidence to support this claim. Although some place names do have a legitimate lineage of clearly recorded phonetic changes, most of them, like Kohaejin and Kangjin, are linked by coincidental phonetic similarities and scholars often employ a circular logic without providing additional supporting evidence.

For the moment, let us assume that the southern port of present-day Kangjin is the Kohaejin mentioned in the Nihon shoki and continue to track the route of the YamatoPaekche military expedition. If that was the case, I argue that the most likely route from the Kaya region to the sea port of Kohaejin would have been along the southern coastline of the Korean peninsula. First, trekking overland from the Naktong River basin (i.e., Kaya) to Kohaejin would have required going through the Sobaek mountain range, which would have been unnecessarily difficult if one could move by sea. This is assuming that the Yamato-Paekche army traveled by ships in the first place. Second, if the expeditionary force had attempted an overland crossing through the Sobaek mountain range, based on the current terrain, they would have had to pass through the Yorngsan River basin to reach the southern port of Kohaejin. Ch'imidarye and the surrendering towns were probably located in the Yongsan River basin. If that is so, then the Yamato-Paekche force would have had to pass those locations to arrive at Kohaejin, and then double back north through the mountains to attack the towns they had just passed through, which seems dubious. In addition, King Kŭnch'ogo expressed interest in securing an ocean trade route with Yamato, so it would have been logical to secure the coastal regions rather than spending resources crossing overland to Kohaejin. Again, this is assuming Kohaejin is Kangjin; ultimately, it is not yet clear where Kohaejin was actually located based on currently available texts.

\section{Ch'immidarye or Tomutare}

Moving on to the next act in the Jingū 49 record, the first clue for determining the location of Ch'immidarye 忱彌多禮 is use of the term “southern barbarian” 南蠻 (Jap. namban; Ch. nanman; Kor. namman). This term was normally used in Chinese historical sources to describe any non-Han 漢 or non-Chinese groups south of the central Chinese core. However, the 'center' of the Jingū 49 narrative would have to have been either Paekche or Yamato. Since the Korean peninsula would have been considered west of the Yamato court, the term "southern barbarian" would not have been applicable from a Yamato perspective. When the Nihon shoki was compiled in the 
early eighth century A.D., Japanese elites viewed the world as consisting of the Emishi 蝦夷 in the northeast region of the Japanese archipelago and the Hayato 隼人 in the southern region of Kyushu. On the other hand, "southern barbarian" does make sense from a Paekche point of view, since Kohaejin and the Yŏngsan River basin were south of its capital (present-day Seoul). This supports the idea that this record was originally written from a Paekche perspective.

As with Kohaejin, the debate on the location of Ch'immidarye revolves around speculative phonetic correspondences. The one most relevant to our discussion is No Chungguk's (2012:60) argument that Ch'immidarye is a phonetic corruption of Sinmi 新爾, the leading polity of the primary Mahan confederation mentioned in the Chinese dynastic source, Jinshu. As mentioned above, he argued that there were two Mahan confederacies: Paekche in the Han River basin and Sinmi in the Yongsan River basin. The element "-darye" (or "-tarye") was probably just a general location suffix, so Ch'immidarye would have been Ch'immi, which he thought sounded like Sinmi.

A problem for No Chungguk's argument is that the original compilers of the Nihon shoki included phonetic glosses in the margins to aid readers in pronouncing certain proper nouns, especially foreign names and place names. One of the interlinear comments in the Nihon shoki glosses Ch'immidarye as "Tomutare" (NS 2[4]:457). While it is possible that the character "ch'im" 忱 was originally "t'am" 耽, but was changed due to copyist error, the phonetic gloss remains unchanged (Kim C. 2011). Therefore, instead of Ch'immidarye, it would have been T'ammidarye, which is closer to the original gloss. The significance of this phonetic choice, as Kim Chŏngbin (2011) argues, is that Tomutare was an old name for Cheju Island, also referred to as T'amna 耽羅國 or T'ammura 耽牟羅 (SGSG 26 [Tongsŏng 20]). The fact that Cheju Island is off the coast of Kangjin (i.e., Kohaejin, according to Kim Chŏngbin 2011) adds circumstantial support for this idea. Additionally, according to the Sanguozhi, the inhabitants of Cheju Island were completely different from the Mahan on the mainland: they spoke a completely different language, shaved their heads, and wore leather clothes with no bottoms (SGZ 30 [Dongyizhuan]:852). From a Paekche perspective, this culturally and linguistically distinct group would have been more likely described as "southern barbarians" than the inhabitants of the Yŏngsan River basin, who like the Paekche were supposedly descendants of the Mahan.

The identification of Tomutare with T'amna contradicts another account in the Nihon shoki that claims that the people of T'amna 耽羅人 (Jap. Tamura) first had contact with Paekche in A.D. 508 (NS 17 [Keitai 2.12]). Additionally, the Samguk sagi records first contact between T'amna and Paekche as occurring in A.D. 476 (SGSG 26 [Munju 2.4]). Therefore, it is not clear if Tomutare was equivalent to T'amna or a completely different location. So far, however, there is no strong evidence that Tomutare was in or represented any part of the Youngsan River basin.

Although the commonly accepted translation of Jingū 49 assumes that the territory of Tomutare was given to Paekche, I argue that the passage suggests that Paekche acquired the port of Kohaejin, not Tomutare. My reasoning is as follows. First, if the Yamato-Paekche force was on its way to Paekche along the coastline of the Korean peninsula, it would have been an unnecessarily large investment of resources to deviate nearly $130 \mathrm{~km}$ south from the coastline of Kohaejin just to "slaughter southern barbarians" on Cheju Island. It is more likely the "southern barbarians" were slaughtered at Kohaejin itself. Furthermore, Paekche wanted to secure trade routes 
along the coast of the Korean peninsula, which would not necessarily have included Cheju Island. If we look at the original text, there is nothing to suggest that the Yamato-Paekche force actually went to Tomutare. However, there is textual evidence that people from Cheju Island came to the mainland for trading purposes (SGZ 30 [Dongyizhuan]: 852), so it is entirely possible that there was a settlement or group of Cheju people at Kohaejin. Finally, the original text does not explicitly say that Paekche gained control over Tomutare.

I interpret the text in the following manner:

至古爱津 Arrived at Kohaejin

屠南蠻忱彌多禮 [while at Kohaejin] slaughtered “southern barbarians” of Tomutare

以賜百濟 Took [Kohaejin] and granted it to Paekche

In other words, the omitted object after 以 (lit. "to take") would make more sense referring back to Kohaejin and not the slaughtered barbarians of Tomutare.

\section{Surrendering Towns}

As for the final act of the Jing $\bar{u} 49$ record, the location of the surrendering towns are also unclear. It is important to note that these were "towns" (J. mura; K. upp 邑) or settlements and not "countries" (J. kuni; K. kuk 國) or states/kingdoms, which further refutes the idea of massive territorial expansion or conquest. The only context given in the Jingū 49 is that King Kŭnch'ogo and his son and their army rendezvoused with the joint Yamato-Paekche force. This suggests that these towns would have been at or near the meeting point of these two forces. The original line (比利辟中布彌支半古四邑 自然降服) has traditionally been translated as the four towns of “Piri 比利, Pyŏkchung 辟中, P'omij 布彌支, and Pan'go 半古” (NS 1994: 457). Yi Tohak (2013), however, attempts to link these towns to Mahan polities mentioned in the Sanguozhi by rereading these characters as the five towns of “Piri 比利, Pyŏkchung 辟中, P'omi 布彌, Chiban 支半, and Kosa 古四.” Three of these towns would then correspond with the Mahan polities of Pulmi 不彌國, Chiban 支半國, and Kuso 狗素國 (Table 1).

According to Yi Tohak (2013), the five surrendering towns were located in North Chŏlla Province, which is not part of the Yŏngsan River basin. If that is the case, the Yamato-Paekche force, after taking Kohaejin, would have moved up along the western coastline of the Korean peninsula and met with King Kŭnch'ogo's force in present-day North Chŏlla Province, where, according to this interpretation, various Mahan polities surrendered to them. The next part of the story seems to confirm this

Table i. Yi Tohak's (2013) Proposed Locations for Surrendering Towns

\begin{tabular}{lll}
\hline TOWN NAME & PRESENT-DAY LOCATION & SANGUOZHI MAHAN POLITY \\
\hline Piri & Poan & $?$ \\
Pyŏkchung & Kimje & $?$ \\
P'omi & Chŏngŭp & Pulmi \\
Chiban & Puan & Chiban \\
Kosa & Kobu & Kuso \\
\hline
\end{tabular}


Table 2. Yŏn Minsu's (2011) Proposed Locations for SURRENDERING TOWNS

\begin{tabular}{ll}
\hline TOWN NAME & PRESENT-DAY LOCATION \\
\hline Piri & $?$ \\
Pyŏkchung & Posŏng \\
P'omiji & Naju \\
Pan'go & $?$ \\
Kosa & Kobu \\
\hline
\end{tabular}

interpretation as King Kŭnch'ogo and the Yamato generals celebrate their successes together at Churyusugi 州流須祇 (NS 9 [Jingū 49]), which corresponds with Churyu Fortress 周流城 at present-day Puan in North Chŏlla Province (Yi T. 2013:120). Once again, all the locations for these place names are still only guessed at, so it is difficult to know for sure. Other scholars have identified the same towns as all being in the Youngsan River basin (Yŏn 2011:235) (Table 2).

Once again, the weakness in any of these schemes is the reliance on speculative phonetic correspondences that generally cannot be proven or disproven without additional evidence or context for interpretation. Even if the surrendering towns were somewhere in the southwest Korean peninsula, it seems most likely they would have been located in coastal areas along the sea route between Kohaejin and the Paekche capital on the Han River, since an overland route would have taken far more resources than moving along the coastline. While the lack of detail in historical texts makes it difficult to say where the towns were located, it is difficult to interpret the capture of only four or five towns as evidence of territorial expansion.

\section{Additional Textual Issues}

Beyond the speculative linguistic analysis of place names, another issue with the Jingū 49 record is the lack of corroborating accounts in other historical sources. For example, the Silla Annals of the Samguk sagi do not include any entry for the year 369, although do record that Silla received a gift of two fine horses from Paekche in the previous year (SGSG 24 [Kŭnch'ogo 23.3]; SGSG 3 [Naemul 13]). This seems an unlikely courtesy in that Silla had just robbed the Paekche envoy the year before in 367, according to the Nihon shoki. In addition, there is no record of a Yamato invasion of any polity in 369 in the Samguk sagi, even though it reports that Wa (i.e., Yamato) raids against Silla were common throughout most of the fourth century. While this could be due to the fragmentary nature of the Samguk sagi or perhaps suppression of negative events, other factors also do not add up. For instance, from a strategic perspective, it is improbable that Paekche would have invested significant resources in southern territorial expansion during a time when Koguryo represented an active threat from the north. According to the Samguk sagi (SGSG 24 [Kŭnch'ogo 24.9]), Koguryŏ invaded Paekche the same year that King Kŭnch'ogo was supposedly conquering the southern Korean peninsula. Although much has been made of King Kŭnch'ogo's military prowess, it seems a stretch for Paekche to have engaged in major military operations in the north and far south in the same year.

Nothing in the original Jingu 49 text supports the idea of a southern expansion or any expansion on the Korean peninsula. Instead, we find the butchering of 
"barbarians" at a possible coastal settlement, a move up the coast where four (or five) towns surrender along the way, and a meeting between the Paekche king and his son with the Yamato and Paekche leaders of the punitive task force against Silla. There is also the possibility that the entire passage is pure fiction or depicts a later or different event that was then repurposed to glorify the Japanese imperial family. In any case, if we take this passage at face value, it is difficult to see it as evidence of a massive territorial expansion of either Paekche or Yamato into the southwestern peninsula in the fourth century.

\section{ARCHAEOLOGICAL PERSPECTIVES}

Due to Yi Pyŏngdo's influential interpretation of the Jingū 49 passage, until at least the 1970s, Korean archaeologists simply considered the southwestern Korean peninsula part of Paekche archaeology. The Yŏngsan River basin at the southwestern tip of the Korean peninsula has a material culture quite different from that of Paekche or any other region on the peninsula, however. Hwang Yonghun (1974) called the Yongsan River basin a "cultural island." Yi Yŏngmun (1978) then described the jar-coffin burial system in the southwestern Korean peninsula as a remnant of Mahan culture. Jar coffin burials contrast with the stepped stone-piled tombs (chŏksŏkch'ong 積石塚) favored by Paekche in the early third century, which evolved into Paekche-style stone chamber tombs in the fourth century. Yi's association of jar-coffin burials with the Mahan gained further traction in the 1980s when Ch'oe Mongnyong (1986) argued that the groups buried in the jar-coffins at the Pannam site (near present day Naju in South Chŏlla Province) were the last holdout of the Mahan (i.e., the Mokchi polity mentioned in the Sanguozhi). Despite this observation, he continued to argue that Pannam and the other groups in the Youngsan River basin had belonged to Paekche.

Two things stand out from the reactions of scholars trying to reconcile Yi Pyŏngdo's (1959) interpretation of the Jing 49 passage with the different complexities found in the archaeological record. First, they seemed to have an almost instinctual desire to ascribe textually-derived cultural groupings to material culture (e.g., nonPaekche material culture in supposed Paekche territory must be a Mahan remnant). Second, by clinging to the idea that the Youngan River basin was in some way part of Paekche from the late fourth century on, they resisted evaluating the archaeology on its own terms. In other words, instead of letting the material record speak for itself, the hegemonic nature of the historical texts drove many of their questions about the archaeological data.

Can we use archaeological evidence to prove or disprove that a southward Paekche invasion occurred in the late fourth century? Such an approach is problematic whenever textually-derived cultural groupings are ascribed to particular material cultures (Davey 2016; D. Lee 2014; von Falkenhausen 1993). Additionally, much of data of the Yơngsan River basin comes from tombs, which Jones (1997) and Meskell (2001) have shown to only have limited utility for making meaningful cultural distinctions, determining the geographic range of a particular group, or identifying an ethnicity or political entity. Finally, and more specifically to Korea, the available dates for most forms of material culture have largely been based on relative chronologies. Compared to "Chinhan" archaeology in the southeastern Korean peninsula, "Mahan" archaeology is relatively new and still developing, so it is difficult to find anything precise or reliable to apply to as specific a historical point in time as A.D. 369. There is 
also the issue that mortuary archaeology in the southwestern Korean peninsula is quite diverse (D. Lee 2014), which makes it difficult to speak of a general "Mahan" group.

Even with all these problems, there is still value in looking at the material record for the Yŏngsan River basin, though interpreting the data must be done critically. To that end, I provide a broad overview of mainstream ideas and dating of Paekche archaeology and the Youngan River basin before and after the year 369.

\section{Paekche and the Youngsan River Basin Third Century Divergence}

Until the third century A.D., there appears to have been some commonalities in burial approaches, such as the low-lying rectangular ditch-enclosure tombs called chugumyo 周溝墓, in communities spanning south from the Han River basin (including presentday western Kyŏnggi Province) through the Ch'ungch'ŏng provinces to the southwestern Chŏlla provinces. Upon closer inspection of these communities, there appear to be regional centers of shared material culture in the Han River basin, Asan Bay, Kŭm River basin, and Yŏngsan River basin, and along the southern coast (Im 2010). Due to their location, many scholars associate these regional centers with the Mahan polities described in the Sanguozhi (Yi Hyŏnhye 2007), but as mentioned above it is difficult to associate any particular regional center with any of the 54 Mahan polities listed, nor am I convinced that it makes sense to do so. Davey (this issue) also addresses the problem of using historical text-based models to delineate archaeological cultures for the southeastern Korean peninsula, which has some parallels to this region. Regardless, the consensus is that Paekche emerged from the Han River basin regional center and began expanding shortly after it was founded.

Starting from around the early third century A.D., the burial systems in the Han River basin regional center began to diverge from the others. As mentioned above, the Han River basin culture (i.e., Paekche) began to favor stepped-style stone-piled tombs. Compared to other tomb styles on the Korean peninsula, these newly developing Paekche tombs were rather plain and seemed to merely by spaces for containing the dead. At this time, burial goods were not very elaborate and consisted mostly of Paekche-style pottery (Kwon 2008). Around the same time, however, elite groups in the Youngsan River basin were developing large U-shaped mounded tombs with lengths exceeding 30 meters; these tombs contained wooden coffins or jar coffins. They also had ditch enclosures and were found constructed on top of low hills or inclines. Burial goods included double-rim pottery, jars with two lugs, wide-mouthed jars with perforated bodies, and cups with necks. Iron knives and helmets were also included in the tombs. Based on the scale of the tombs and the richness of the burial goods, Im Yŏngjin (2012:86) argues that these burials were "equal" to Paekche's and speculates that the tombs probably represented some of the larger Mahan polities mentioned in the Sanguozhi.

Jar Coffin Tombs - The most unique trait of the Yŏngsan River basin burials is the large-scale jar coffin, which appears nowhere else in the Korean peninsula. Jar coffins of this kind first appeared in the early third century A.D. in the upper reaches of the Komak River 古幕川, a tributary off of the Yŏngsan River in the northwestern region of the Youngsan River basin. Jar coffins began displacing the wooden coffins that were commonplace throughout the region. They spread throughout the Yŏngsan River basin into the present-day Koch'ang and Yŏnggwang regions and continued to be used 
until the early sixth century, when they were displaced entirely by Paekche-style burials (D. Lee 2014). Throughout the fourth and early fifth century, the jar coffin burial system seemingly continued to develop on its own with very little outside influence from neighbors such as Paekche or Kaya. During the same period, the U-shaped mounded tombs evolved into larger mounded round or square tombs.

Another significant difference between Yŏngsan River basin burials and others on the Korean peninsula is the use of the burial space. Most mounded tombs in the Korean peninsula, including Paekche, contained one corpse, but a single mounded tomb from the Yŏngsan River basin would contain multiple generations and would expand vertically as more burials were built successively on top of each other. This is a completely different burial grammar than found at Paekche or in any other burial system on the Korean peninsula. These tombs were surrounded by ritually-placed earthenware and large quantities of discarded ritual objects were found in the ditch enclosures. The central hub for this type of tomb was the Pannam region, which became the largest site for these tombs until the early sixth century A.D.

\section{Relationship between Paekche and the Youngsan River Basin}

The next question is the Yŏngsan River basin's relationship with Paekche, particularly in the fourth century A.D. Curiously, as far as this author is aware, no Paekche prestige goods have ever been found in any tomb in the Yŏngsan River basin prior to the late fifth century A.D., yet they begin appearing in great numbers in the late fifth century. Due to the fragmentary nature of the material record and possible errors in relative dating, we cannot assume the region had no contact with Paekche. However, based on current understanding of the data, the late fifth century marks the beginning of the inclusion of Paekche prestige goods in Yŏngsan River basin burials (D. Lee 2014). If a Paekche invasion of the southwest did occur in A.D. 369, it did not lead to any immediate changes to the burial culture there. One could argue that burials are highly conservative and do not necessarily reflect any political changes. It is also possible that a recently conquered and resentful local population could have rejected an influx of Paekche material culture or the Paekche may have withheld prestige goods from the locals, but it is difficult to determine based on the data that we have. On the other hand, Yi Hŭijun (2007), Kim Yongsŏng (2009, 2015), and Yi Sŏngju (S. Lee 2016) argue convincingly that Silla's expansion throughout the southeastern Korean peninsula can be seen in the distribution of prestige goods produced in the core regions to peripheral areas that had recently been conquered or assimilated. If this pattern also holds true for Paekche, one could argue that Paekche prestige goods should have started appearing in the southwestern Korean peninsula soon after the presumed invasion of 369. However, we only see the appearance of Paekche-style burials and fortresses in the Yŏngsan River basin starting in the late fifth century with full assimilation by the early sixth century (D. Lee 2014).

Im Yŏngjin (1995) argues that the people who built multigenerational jar burial tumuli in the Yŏngsan River basin were probably "remnant Mahan" who had so far avoided assimilation by Paekche. Regardless of the identity of these peoples, their burial culture indicates that they were clearly neither part of the Paekche nor Yamato cultural spheres. Recognizing the independent nature of the Youngsan River basin, some scholars such as Kang Pongnyong (1998) completely reject the use of textuallyderived labels of identity and use the term "jar-coffin tomb society" instead. Yet these 
scholars are still in the minority when it comes to treating the Youngsan River basin as an independent entity in the late fourth century A.D.

This exercise in speculation shows the power that the Jingū 49 record and other historical texts have on our view of the material record. The mere absence of Paekche material culture in the southwestern Korean peninsula in the late fourth and early fifth century A.D. does not make a compelling archaeological case against a southern invasion by King Kŭnch'ogo, since the material record remains extremely fragmentary due to the lack of a comprehensive archaeological survey of the region. Nevertheless, it is interesting to see the expected signs of Paekche influence and assimilation only appearing nearly a century after the purported invasion, assuming that the current chronology is correct. Paekche assimilation of the Youngsan River basin in the early sixth century is also supported by the fact that the jar burial tradition continues there until that time before being completely displaced by Paekche-style burials.

\section{CONCLUSION}

The theory that the Paekche King Kŭnch'ogo conquered the southern peninsula in the late fourth century is ultimately based on a creative twentieth century re-imagining of a punitive Yamato mission against Silla found in a problematic Japanese historical text. The extent of the "conquest" reported in the Jingu 49 record is a place called Kohaejin and four (possibly five) towns. This hardly describes a major territorial expansion by either Yamato or Paekche. During Imperial Japan's rule over Korea, Suematsu Yasukazu (1961) first reinterpreted this account as a conquest in an attempt to show that ancient Japan had ruled the Korean peninsula. However, there is no sound evidence for this interpretation. In a reaction to this Japanese imperialist historiographical view, Yi Pyŏngdo (1959) merely replaced the main actor in the drama, Yamato, with a Korean polity, Paekche, but left the problematic conquest aspect of the narrative intact. King Kŭnch'ogo already had a reputation for military prowess due to his victories over Koguryŏ, so adding an additional southern conquest would have made sense for this Korean cultural hero, even if the original source of the text was Japanese and its interpretation as a conquest ironically originated from Japanese imperialism.

If the Jingu 49 passage has any historical truth to it, I argue that it more likely reflects a collaboration between Yamato and Paekche to secure a coastal trade route between Paekche, Kaya, and Yamato. The military force consisted of a joint command by Yamato and Paekche military officials. This small elite force probably captured the coastal settlement of Kohaejin and then continued to move up the western coast of the Korean peninsula to meet up with King Kŭnch'ogo and his son, who were probably moving their way south along the coast from their base in the Han River basin. This idea is further supported in a speech made by Paekche King Sŏng (r. 523-554) in A.D. 541 when he allegedly claimed that Paekche's interest in Kaya (and by extension the Japanese archipelago) began with King Kŭnch'ogo (NS 19 [Kinmei 2.4]). As the Kohaejin example suggests, territorial conquest would have been limited to settlements along the coast and not an overland invasion throughout the southern Korean peninsula.

The relevance of the Jingū 49 record to Korean archaeology lies in its hegemony as a text. Yi Pyŏngdo's (1959) unchallenged re-imagining of the text and subsequent canonization of Paekche King Kŭnch'ogo's southern expansion into Korean 
nationalist historiography has colored how Korean archaeologists interpret the material record of the southwestern Korean peninsula. Due to its many textual issues, using the Jingu 49 record to interpret the archaeology of the region is highly problematic. Looking at currently available archaeological data on their own terms, the Yŏngsan River basin seems to have developed independently on the Korean peninsula throughout the late fourth and early fifth centuries, as indicated by its multi-generational jar burials. This is in sharp contrast to the rapid developments that happened in the late fifth century A.D., when the Yŏngsan River basin began dramatically experimenting with different types of tombs and constructions methods, including the famous keyhole-shaped tombs from the Japanese archipelago (D. Lee 2014). By the early sixth century A.D., however, burials followed the same format as Paekche elite burials.

Even if we take relative rather than absolute dating of these tombs and artifacts into account, the idea that Paekche conquered the southwestern Korean peninsula is still solely based on a very problematic historical narrative which has heavily influenced the interpretation of the material record. Suggestions that current chronologies could be off by a century in order to match them up with the A.D. 369 date and even the need to "prove" or "disprove" that this historical event occurred are both indicative of the power that hegemonic texts can have over interpretations of the material record. Except for a few scholars such as Im Yŏngjin (1995), the general consensus continues to be that Paekche had some form of control over the entire southwestern Korean peninsula since A.D. 369. This idea is found throughout Korean academia, textbooks on Korean history, and nearly all maps depicting Paekche's territorial expansion.

Based on a critical reading of the Jingū 49 record, it is unlikely that either Paekche or Yamato conquered the southwestern Korean peninsula in A.D. 369. There is also no compelling archaeological evidence such as epigraphy or finding Paekche prestige goods in late fourth century elite tombs in the Youngsan River basin to support the conquest theory. If there is any truth to the Jing $\bar{u} 49$ record, it is more likely a reflection of Paekche and/or Yamato having secured coastal trade routes along the western Korean peninsula on the way to the Japanese archipelago and that this started during King Künch'ogo's reign. Ultimately, this is a cautionary tale of using historiographically twisted texts to understand the archaeological record. If we are not vigilant in critically assessing our historical assumptions, we could end up doing another Jingū 49.

\section{NOTES}

1. Scholars often cite passages or chapters in these ancient royal chronicles by the name of the ruler, the year of his or her reign, and sometimes the month of the year when the recorded event took place. I have included such information in square brackets following the volume number. For example, an event that occurred on the first month of the $27^{\text {th }}$ year of King Kŭnch'ogo's reign, as recorded in vol. 24 of the Samguk sagi, would be cited: (SGSG 24 [Kŭnch'ogo 27.1]). Where I cite a chapter by number as listed in an archive, it will also be in square brackets, sometimes followed by page number if available (e.g., NS 2[4]:457).

2. Mimana can either refer to a specific part of the Kaya region called Mimana or the entire Kaya region itself depending on the context of the historical text. It is mentioned in the Kwanggaet'o stele, but there is considerable debate on where it was located in the Kaya region (Hatada 1979). The Kaya region is generally considered the area including and surrounding the Naktong River basin.

3. The Paekche Annals of the Samguk sagi admit that written historical records only begin with Kŭnch'ogo's reign. The fact that events and personages recorded in the Paekche Annals are corroborated in non-Korean sources starting from the mid-fourth century A.D. supports this claim. One prime example is the appearance of King Kunch'ogo in the Nihon shoki as Shōko 肖古 (K. Ch'ogo) and the Jinshu as Yu Gou (K. Yǒ Ku) 餘句. Kŭnch'ogo literally means “the recent Ch'ogo" or Ch'ogo II, to distinguish him from another Paekche ruler by the name of Ch'ogo who 
reigned A.D. 166-214. As Jonathan Best (2006:428-431) notes, the original Ch'ogo was probably fictitious and the historical Ch'ogo would have been Kŭnch'ogo. For a more detailed discussion of this naming issue, see Jonathan Best's (2006) excellent translation of the Paekche Annals.

4. King Kŭnch'ogo and Crown Prince Kŭn'gusu successfully invaded Koguryŏ and assaulted P'yŏngyang Fortress, where King Kogugwŏn of Koguryŏ was killed. This was a major victory for Paekche.

5. It is important to note that since this is hagiography, many of the trade or diplomatic relations are framed as tributary relationships from the Yamato court's perspective. Paekche and Silla were never under Yamato control.

6. Nobody knows exactly what “wake 別” denoted, but it was probably an honorific suffix or title.

7. Kabane were titles denoting rank and political standing in the Yamato court.

8. According to the Silla Annals of the Samguk sagi (2004), the Wa (i.e., Yamato) raided Silla twice during the $9^{\text {th }}$ and $39^{\text {th }}$ years of Isagŭm Naemul's reign (r. A.D. 356-402).

9. Note that the element "jin" (津) means port or crossing, so it is not a fixed part of these place names.

10. Note that “so" (所) means place or location, so it may not be a fixed part of the place name Kugyeso.

\section{REFERENCES CITED}

Best, Jonathan

2006 A History of the Early Korean Kingdom of Paekche: Together with an Annotated Translation of the Paekche Annals of the Samguk Sagi. Cambridge, MA: Harvard University Asia Center.

Ch'oe Mongnyong 崔夢龍

1986 Kogohakchŏk ch'ŭngmyŏn esŏ pon Mahan 고고학적 측면에서 본 마한 [Mahan as seen through archaeology]. Mahan-Paekche munhwa 마한-백제 문화 9:5-15.

DAVEY, JACK

2016 Unreliable narratives: Historical and archaeological approaches to Early Silla. Seoul Journal of Korean Studies 29(1):7-32.

HATADA, TAKASHI

1979 An interpretation of the King Kwanggaet'o inscription, trans. V. Dixon Morris. Korean Studies $3: 1-17$.

HwANG YONGHUN 황용훈

1974 Yŏngam Naedong-ni onggwanmyo chosa pogo 靈岩 內洞里 隹棺墓 調査報告 [Report on the Yŏngam Naedong-ni Jar-Coffin Tombs]. Seoul: Kyŏnghŭi Taehakkyo Pangmulgwan.

IM YŎNGJIN 林永珍

1995 Mahan ŭi hyŏngsŏng kwa pyŏnch’ŏn e taehan kogohakchŏk koch’al 마한의 형성 과 변천에 대한 고고학적 고찰 [Archaeological investigation of the formation and change of the Mahan], in Samhan ŭi sahoe wa munhwa 三韓의社會와文化 [Samhan Society and Culture]: 93-121, ed. Han'guk Kodaesa Yŏn'guhoe 한국고대사연구회. Seoul: Sinsŏwŏn.

2010 Myoje rŭl t'ong hae pon Mahan ŭi chiyŏksŏng kwa pyŏnch'ŏn kwajŏng: Paekche wa ŭi kwan'gye rŭl chungsim ŭro 묘제를 통해 본 마한의 지역성과 변천 과정: 백제와의 관계를 중심으로 [Mahan's regionality and change as seen through burial systems: Relations with Paekche]. Paekche hakpo 백제학보 3:25-46.

2012 3-5-segi Yŏngsan'gang yuyŏkkwŏn Mahan seryŏk ŭi sŏngjang paegyŏng kwa han'gye 3-5 세기 영산강 유역권 마한세력의 성장 배경과 한계 [The circumstances and limits to the growth of Mahan power in the Yŏngsan River Basin in the $3^{\text {rd }}-5^{\text {th }}$ centuries], in Paekche wa Yŏngsan'gang 백제와 영산강 [Paekche and the Yŏngsan River]: 83-132, ed. Sŏng Chŏngyong 성정용. Seoul: Hagyŏn Munhwasa.

JINSHU 晉書 [JS]

2018. Jinshu 晉書 [Book of Jin], available from Scripta Sinica (website), Hanji Dianzi Wenxian Ziliaoku 漢籍電子文獻資料庫 [online database of Chinese classics], accessed 14 April 2018, hanchi.ihp.sinica.edu.tw/ihp/hanji.htm. Taipei: Academia Sinica.

JONES, SIÂN

1997 The Archaeology of Ethnicity: Constructing Identities in the Past and Present. London: Routledge.

KAng Pongnyong 姜鳳龍

1998 5-6-segi Yŏngsan'gang yuyŏk 'onggwan kobun sahoe' ŭi haech'e 5-6 세기 영산강유역 '옹관고분사회'의 해체 [The dissolution of 'Jar Coffin Tomb Society' in the Youngsan River basin in the $5^{\text {th }}-6^{\text {th }}$ centuries], in Paekche ŭi chibang t'ongch' $i$ 百濟自 地方統治 [Paekche Regional Control]: 219-261, ed. Han'guk Sanggosa Hakhoe 韓國上古史學會. Seoul: Hagyŏn Munhwasa. 
KIM CHŎNGBIN 金正涁

2011 Ch’immidarye ko ‘枕彌多禮'攻 [Chi'mmidarye revised]. Kugyŏl youn'gu 구결연구 26 (February):243-268.

KIM YONGSŎNG 金龍星

2009 Silla wangdo ŭi koch'ong kwa kŭ chubyŏn 신라왕도의 고총과 그 주변 [Silla Royal Tombs and Its Periphery]. Seoul: Hagyŏn munhwasa.

2015 Silla kobun kogohak ŭi t'amsaek 신라 고분고고학의 탐색 [Archaeological Investigation of Silla Mounded Tombs]. Seoul: Chininjin.

KOJŎN KANHAENGHOE 古典刊行會

1994 Sinjŭng Tongguk yŏji sŭngnam 新增東國輿地勝覽 [New Augmented Survey of the Geography of Korea], trans. Kojŏn Kanhaenghoe 古典刊行會. Seoul: Sŏgyong Munhwasa.

KwON, OH Young [Kwŏn OYŎNG]

2008 Recent archaeological discoveries \& research on Paekche history, in Early Korea 1: Reconsidering Early Korean History through Archaeology: 65-112, ed. Mark Byington. Cambridge, MA: Early Korea Project, Korea Institute, Harvard University.

Lee, Dennis

2014 Keyhole-Shaped Tombs and Unspoken Frontiers: Exploring the Borderlands of Early KoreanJapanese Relations in the $5^{\text {th }}-6^{\text {th }}$ Centuries. Ph.D. diss. University of California, Los Angeles.

LeE, Sungjoo [Yi SŏngJu]

2016 Recent discoveries in Silla settlement archaeology. Seoul Journal of Korean Studies 29(1):33-64.

MESKILL, LyNN

2001 Archaeologies of identity, in Archaeological Theory Today: 187-213, ed. Ian Hodder. Cambridge: Polity Press.

NiHON SHOKI 日本書紀 [NS]

1994 Nihon shoki 日本書紀 [Chronicles of Japan], vol. 2-4. trans. Kojima Noriyuki. Shinpen Nihon koten bungaku zenshū 新編日本古典文学全集 [Collection of Ancient Japanese Texts (New Edition)]. Tokyo: Shogakkan.

No ChungGuK 盧重國

2012 Munhŏn kirok ŭl t'ong hae pon Yŏngsan'gang yuyŏk: 4-5-segi rŭl chungsim ŭro 문헌 기로을 통해 본 영산강 유역: 4-5세기를 중심으로 [The Yŏngsan River basin as seen through texts: $4^{\text {th }}-5^{\text {th }}$ century], in Paekche wa Yŏngsan'gang 백제와 영산강 [Paekche and the Yŏngsan River]: 31-82, ed. Sŏng Chŏngyong 성 정용. Seoul: Hagyŏn Munhwasa.

SAMGUK SAGI 三國史記 [SGSG]

2004 Samguk sagi 三國史記 [Historical Records of the Three Kingdoms], comp. Kim Pusik 金富軾 trans. Kang-lae Lee 이강래. Seoul: Han'gilsa.

SANGUOZHI 三國志 [SGZ]

2018 Sanguozhi 三國志 [Records of the Three Kingdoms], available from Scripta Sinica (website), Hanji Dianzi Wenxian Ziliaoku 漢籍電子文獻資料庫 [online database of Chinese classics], accessed 14 April 2018, hanchi.ihp.sinica.edu.tw/ihp/hanji.htm. Taipei: Academia Sinica.

SuEMATSU YASUKAZU 末松保和

1961 Mimana kōbōshi 任那興亡史 [A History of the Rise and Fall of Mimana]. Tokyo: Yoshikawa Kōbunkan.

SZCZESNIAK, BOLESLAW

1952 Some revisions of the ancient Japanese chronology Ojin Tenno period. Monumenta Nipponica 8 $(1-2): 1-14$.

TANAKA TOSHIAKI 田中俊明, ED.

2008 Chōsen no reikishi: senshi kara gendai 朝鮮の歴史: 先史から現代 [Korean History: From Prehistory to Modern Times]. Kyoto: Shōwadō.

TSUDA SŌKICHI 津田左右吉

1913 Chōsen Rekishi Chiri Dai-2-ken [Korean Historical Geography, vol. 2] 朝鮮歷史地理, 第2卷. Tokyo: Minami Manshū tetsudō kabushiki gaisha 南滿洲鐵道株式會社.

VON Falkenhausen, Lothar

1993 On the historiographical orientation of Chinese archaeology. Antiquity 67(257):839-849.

Yi HǔIJUN 李熙濬

2007 Silla kogohak yŏn'gu 신라고고학연구 [Studies on Silla Archaeology]. Seoul: Chininjin. 
YI HYŎNHYE 李賢惠

2007 Mahan sahoe ŭi hyŏngsŏng kwa palchŏn 마한 사회의 형성과 발전 [The formation and development of Mahan society], in Paekche ŭi kiwŏn kwa kŏn'guk 백제의 기원과 건국 [The Origin and Establishment of Paekche]: 218-249. Kongju: Ch'ungch'ŏngnam-do Yŏksa Munhwa Yŏn'guwŏn 충청남도역사문화연구원.

YI PYŎNGDO 李丙壽

1959 Paekche ŭi hŭnggi wa Mahan ŭi pyŏnch'ŏn 백제의 흥기와 마한의 변천 [Paekche’s expansion period and the change of Mahan], in Han'guksa: Kodaep'yŏn 韓國史: 古代篇 [Korean History: The Ancient Period]: 337-361, ed. Chindan Hakhoe 진단학회. Seoul: Uryu Munhwasa.

1976 Han'guk Kodaesa Yŏn'gu 韓國古代史研究 [Ancient Korean History]. Seoul: Pagyŏngsa.

YI TOHAK 李道學

2013 Yŏngsan'gang yuyŏk Mahan cheguk ŭi ch'ui wa Paekche 榮山江流域 馬韓諸國의 推移와 百濟 [Developments of the Mahan polities in the Yơngsan River basin and Paekche]. Paekche munhwa 백제문화 49:109-128.

YI YŎNGMUN 李榮文

1978 Yŏngsan'gang haryu chiyŏk ŭi kobun'gun: Naju Pannam-myŏn kobun'gun ŭl chungsim ŭro 榮山江 下流地域의 古墳群: 羅州 潘南面 古墳群을 中心으로 [The cemeteries of the lower reaches of the Yŏngsan River: Naju Pannam-myŏn cemetery], in Naju Taean-ni 5-ho Paekche sŏksilbun palgul chosa pogo 羅州 大安里 5 號百濟石室墳 發掘調査 報告 [Naju Taeanni Tomb 5 Paekche Stone Chamber Tomb Excavation Site Report]. Naju: Naju Kunch’ŏng.

YŎN MINSU 延敏洙

2011 Yŏngsan'gang yuyŏk ŭi chŏnbang huwŏnbun p'ijangja wa kŭ sŏngkyŏk 영산강유역의 前方 後圓墳 羊장자와 그 성격 [The interred and characteristics of the Yŏngsan River basin keyhole tombs]. Ilbonhak 일본학 32:225-259. 